\title{
The Effect of Selection and Training Process on Competency and Its Impact on Employee Performance in Pt. Nok Indonesia
}

\author{
Memi $^{1} \quad$ Yanti Murni ${ }^{2}$ \\ Mercu Buana University Jakarta \\ Jl. Meruya Selatan No.1, Kembangan, Jakarta Barat
}

\begin{abstract}
Organization is not able to run the operations of the company to developed without the people behind the organization. Human resources would require competence in their respective fields so that the activities and corporate objectives can be achieved. In order to get competent employees, support of the selection process and training adequate is highly required. The research model was tested on PT NOK Indonesia as the object of research. This research aims to know the influence of the selection process and trainning of competence and its impact on the perfomance of the employees at PT NOK Indonesia. The object of this study is the employees of production section 4 on PT NOK Indonesia. Population in this study were employees of PT NOK Indonesia at departement of production section 4 totaling 178 people. This sample was done to 64 respondents by using incidental sampling technique. Data analysis that is used in this research was SEM-PLS with the help of SmartPLS 3.0 software. The results show that the selection process and training process has the positive and direct significant influence to the perfomance of the employees. Furthermore, the selection process and training has the positive and insignificant indirect influence to the perfomance of the employees.
\end{abstract}

Keywords: Selection process, Training, Competence, Employee perfomance

DOI: $10.7176 / \mathrm{EJBM} / 11-21-19$

Publication date:July $31^{\text {st }} 2019$

\section{PRELIMINARY}

Today, globalization is making business competition tighter. Companies must be able to compete with other companies in maintaining the existence and survival of the company. Every organization will not be able to progress and develop without people competent in it. Therefore human existence in the organization is an important and inseparable part of the company's operational activities in order to achieve the objectives to be achieved. In reality, what is happening now is the process of selecting or seeking employees by involving third parties, namely consulting services (foundations). Using consultant services for the selection process may not be a problem for large companies, if it involves costs. However, there are certain influences that result in the selection or recruitment process not being able to run as a whole, like the selection procedure or tests carried out only to the extent of formality. In a management error in selecting will have an impact on the performance of the company, because the company will have the burden to bear the new workforce while in the company.

Other things that become stumbling blocks in a company's journey are the difficulty of maintaining workers when the company is in trouble, nowadays the organization is seen by some as an act of weak heart and low in mind. Therefore, having employees with workers' status is still considered to be a lot of disadvantage compared to having employees with contract worker status or commonly known as outsourcing employees, many of whom say that outsourcing employees are workers who are nothing more than a supplementary production rental object.

From the company's target data per month decreases every month. Based on the total number of orders over a period of 12 months as many as 112049 pcs which can be realized or that can only be done by employees as many as 110005 pcs, the growth rate is negative 2044 pcs with an average percentage per month in a negative condition of $196.9 \%$. It can be said that the target set by PT NOK Indonesia in 12 months was not achieved by the employees owned by the company. This condition indicates the existence of problems in the performance of PT NOK Indonesia employees. Employee performance is highly highlighted and there are other factors, namely the frequent process of selecting new employees every month.

\section{STUDY OF LITERATURE}

\section{Selection Process}

According to Marwansyah (2016: 106), Selection is "The Process the person or person who best meets the selection criteria for the position available, considering the current environmental conditions". As for Suwanto and Priansa (2016: 88), Selection is a process to decide the right employee from a group of prospective employees obtained through the recruitment process, both internal and external recruitment. While Suparyadi (2015: 149), Selection is a process for selecting prospective employees who have a match between individual characteristics with the specifications of the work that will be carried on it.

There are several dimensions in the selection process as follows, Simamora (2015): (1) Education (2) References (3) Experience (4) Ability to use English (5) Health (6) Written tests and (7) Interview tests. 


\section{Training}

According to Suwanto and Priansa (2016: 118), Training means systematic changes from Knowledge, Skill, Attitude and Behavior that continue to experience improvements that each employee has by being able to realize the goals of an organization or company in fulfilling desired HR standards . Meanwhile, Sikula (in Sutrisno, 2016: 67), said that training is a short-term educational process that uses systematic and organized procedures, in which non-managerial workers learn knowledge and technical skills for certain purposes.

Whereas according to Suparyadi (2015: 185), Training is defined as a systematic learning process that includes mastery of knowledge, improving skills, and changes in attitudes and behaviors to improve employee performance. The indicators used, Mangkunegara (2011: 57): (1) Instructors (2) Participants (3) Materials (4) Methods and (5) Objectives.

\section{Competence}

According to Suparyadi (2015: 243), Competence is a combination of knowledge, skills or expertise, and values or attitudes or behavior of individuals. Sutrisno (2016: 203), Competence is an ability based on skills and knowledge supported by work attitudes and their application in carrying out tasks and work in the workplace that refers to the specified work requirements. As according to Marwansyah (2016: 36), Competence is a combination of knowledge, skills, attitudes and other personal characteristics needed to achieve success in a job, which can be measured using agreed standards, and which can be improved through training and development. The elements used to fulfill the competencies are as follows, Edison, Anwar and Komariyah (2017): (1) Knowledge (2) Expertise and (3) Attitude.

\section{Performance}

According to Marwansyah (2016: 228), Performance is the achievement or achievement of a person regarding the tasks assigned to him. Whereas according to Suwanto and Priansa (2016: 196), performance is a performance or performance. Performance can also be interpreted as work performance or implementation of work or results for work. According to Suparyadi (2015: 299), employee performance, basically is an effort to manage the ability of employees carried out by the organization systematically and continuously so that employees have the level of performance expected by the organization, which is able to provide optimal contribution, so that organization goals. Indicators used, Edison, Anwar and Komariyah (2017): (1) Target (2) Quality (3) Time of Settlement and (4) Obedient principles.

\section{Relationship between Selection Process and Competence}

Utami, Desi (2013) the selection process has a positive and significant influence on competence, namely considering academic ability in the field of management. Sitorus and Ghozi (2014), the employee selection process was increased so that employee competencies increased as well. Supported by Faradina, Dinda (2015), the selection process has a significant effect on competence.

$\mathrm{H}_{1}$ : There is a significant influence from the selection process on employee Competencies

\section{Relationship Training with Competence}

Wisastra and Sagala (2016) one of the dimensions that has the greatest influence on employee competency is the training method and then followed by the training goals and objectives and the least influential dimension is the quality of the coach. Purnomo, Sudana and Mananda (2016), education and training have a positive and significant influence on performance. Dispingping Raharjo, Paramita and Warso (2016) states that job training has a significant effect on work competence.

$\mathrm{H}_{2}$ : There is a significant effect of training on employee competencies.

\section{Relationships Competency with Employee Performance}

Rizki, Muhammad (2017), Competency variables have an influence on employee performance. It is supported by Nurzaman, Nanan (2013), competence has a positive and significant effect on performance. Then F, Ahrul Tsuni (2013) in his research found that competence does not have a positive and significant effect on employee performance.

$\mathrm{H}_{3}$ : There is a significant effect of competence on employee performance.

\section{Relationship between Selection Process and Employee Performance}

Kartodikromo, Bernhard, and Trang (2017) in their research found that the selection process simultaneously had a significant effect on employee performance. Then Renaldo, Lengkong, and Maniharapon (2016) in their study found that from the regression and partial tests between employee selection and employee performance there were positive and significant influences. After that Ekwoaba, Ikeije. U and Ufoma (2015) in their study found that the selection criteria had a significant influence on employee performance. 
$\mathrm{H}_{4}$ : There is a significant effect of the selection process on employee performance.

\section{Relationship Training with Employee Performance}

Saluy (2019), concluded that there was an influence between the training on the performance of Military / TNI personnel in the National Civil Service Commission I. Ataunur and Ariyanto (2015) in their study found that job training had a significant effect on work competencies. And work competency has a significant positive effect on employee performance. Then Dwihatmojo, Nelwan and Kawet (2016) in their study found that simultaneously and partially, training had a positive and significant effect on employee performance. Besides that, Purnomo, Sudana, and Mananda (2016) in their research found that training had a positive and significant influence on performance directly.

$\mathrm{H}_{5}$ : There is a significant effect of training on employee performance.

Relation of Selection Process to Employee Performance with Competence as Intervening Variable Tigor and Ghozi (2014), in their research found that the influence of employee competency mediation or the direct influence of employee selection processes on employee performance was stronger and more significant. According to Warsinah (2014), in his research found that the selection process had a positive and significant direct and indirect effect on employee performance.

$\mathrm{H}_{6}$ : There is a significant effect of the selection process on employee performance with competence as an intervening variable.

\section{Relation of Training to Employee Performance with Competence as Intervening Variable}

Danang, Sudana and Mananda (2016), in their research found that education and training had a positive and significant influence on the performance of Bali guides directly and indirectly. Raharjo, Paramita and Mukeri (2016), in their study found that training research had a significant direct and indirect effect. Then Ekaningsih, Ana Sri (2013), in his research found that self competence was proven to mediate the influence of education and training on improving the quality of apparatus resources. According to Warsinah (2014), in his research found that training had a positive and significant direct and indirect effect on employee performance.

$\mathrm{H}_{7}$ : There is a significant effect of training on employee performance with competence as an intervening variable.

\section{RESEARCH METHODS}

In this study using explanatory research is a causal relationship between the research variables which then tests the hypotheses that have been formulated. This research was conducted at the company PT NOK Indonesia located in MM2100 Industrial Estate Jl. Sulawesi II Blok F 3-4 Cikarang Barat Bekasi-17520, West Java. The study was conducted for nine months starting from August 2018 to February 2019.

The population in this study were employees of PT NOK Indonesia, amounting to 178 employees. In determining the number of samples in this study, researchers used the Slovin formula with a margin of error of $10 \%$, then the number of samples that will be used in this study to obtain 64 respondents. The data analysis used in this study is descriptive statistical analysis techniques and Structural Equation Modeling (SEM) analysis with the help of SMARTPLS 3.0 application.

\section{RESEARCH RESULTS ANALYSIS}

\section{Descriptive Statistics Test Results}

Based on the results of the descriptive statistical test in this study can be known:

- The average calculation (mean) of the performance distribution is 3,631, which means that respondents generally answer agree on the statement in the questionnaire for performance variables.

- The average calculation (mean) of competency distribution is 3.506, which means that respondents generally answer agree on the statement in the questionnaire for competency variables.

- The average calculation (mean) of the distribution of the selection process is 3.507 , which means that respondents generally answer agree on the statement in the questionnaire for the selection process variable.

- The average calculation (mean) of the training distribution is 3.516, which means that respondents generally answer agree on the statement in the questionnaire for training variables.

\section{Evaluation Results of Measurement Model (Outer Model) Test Results for Convergent Validity}

Based on the results of the convergent validity test in this study, it can be seen as many as 3 indicators that have an outer loading of less than 0.6, namely: PS6, PS10, and PS12. Therefore, all three indicators will be removed from the model.

The results of the modification of the convergent validity test can be seen, that all indicators have met convergent validity because the outer loading value is more than 0.6. 


\section{Test Results Average Variance Extracted (AVE)}

Besides being seen from the outer loading, the convergent validity test can also be seen from the results of average variance extracted (AVE). Based on the results of the average variance extracted (AVE) test it can be seen that the construct values for all variables, namely: Performance, Competence, Training and Selection Process have a value of more than 0.5 . So, there is no problem of convergent validity on the tested model.

\section{Test Results for Discriminant Validity (Fornell-Larcker Criterion)}

Based on the discriminant validity test, it can be seen that the root average variance extracted $(\sqrt{A V E})$ square value of the four latent variables are: Performance $=0.817$, Competence $=0.767$, Training $=0.763$, and Selection Process $=0.740$. These values are greater than the correlation of each construct compared to other constructs. Based on the root average variance extracted $(\sqrt{A V E})$ square value above, the construct in the estimated model meets the criteria of discriminant validity.

\section{Test Results for the Reliability of Construction Reliability}

The test results of the validity of construct reliability can be seen from the values of Cronbach's Alpha and Composite Reliability. Cronbach's Alpha value of the four latent variables, namely: Performance $=0.875$, Competence $=0.825$, Training $=0.896$ and Selection Process $=0.896$. Composite Reliability Value of the four latent variables, namely: Performance $=0.909$, Competence $=0.877$, Training $=0.917$ and Selection Process $=$ 0.915. Based on Cronbach's Alpha Values and Composite Reliability, the four latent variables show values of more than 0.7 , which means that all latent variables in this study are declared reliable. This means that the statement items used in this study are able to obtain consistent data, in the sense that if the statement is submitted again, a relatively similar answer will be obtained.

\section{Evaluation Results of Structural Models (Inner Model) \\ $\mathbf{R}^{2}$ Test Value}

Based on the test results the value of $\mathrm{R}^{2}$ can be seen from the Adjusted $\mathrm{R}$ Square $\left(\mathrm{R}^{2}\right)$ value of model 1 is $62 \%$. That is, the number means that the influence of the independent variable (free) is the Selection Process, Training on the dependent variable (bound) namely Performance in this study is $62 \%$ and the remaining $38 \%$ is influenced by other variables not included in this study, such as: discipline, career paths, motivation, and so on. And the second R Square value is $0.541=54.1 \%$. This number means that the influence of independent variables (free), namely the Selection Process, Training and intervening variables (between) namely Competence affects Performance is equal to $54.1 \%$ and the remaining $45.9 \%$ is influenced by other variables not included in this study, such as discipline, career paths, motivation, and so on.

\section{Effect Size Value Test result $\mathbf{f}^{2}$}

a. $\mathbf{f}^{2}$ performance results

$$
\mathrm{f}^{2}=\frac{R_{\text {included }}^{2}-R_{\text {excluded }}^{2}}{1-R_{\text {included }}^{2}}=0,632
$$

The result of the $f^{2}$ value of the endogenous variable Performance is 0.632 , where the value is interpreted that the latent variable predictor has a strong influence on the structural level.

\section{b. $\mathbf{f}^{2}$ Competency results}

$$
\mathrm{f}^{2}=\frac{R_{\text {included }}^{2}-R_{\text {excluded }}^{2}}{1-R_{\text {included }}^{2}}=0,179
$$

Hasil nilai $\mathrm{f}^{2}$ dari variabel endogen Kompetensi adalah sebesar 0,179 yang dimana nilai tersebut diinterpretasikan bahwa prediktor variabel laten memiliki pengaruh kuat pada level struktural.

\section{$Q^{2}$ Value Test Results}

$\mathrm{Q}^{2}=1-\left(1-R_{1}^{2}\right)\left(1-R_{2}^{2}\right)=0,826$

From the results of $\mathrm{Q}^{2}$ calculations above, it is known that the value of $\mathrm{Q}^{2}$ or the predictive value of relevance is 0.826 . The meaning of 0.826 shows that the model has predictive relevance because the value of $\mathrm{Q}^{2}$ is greater than 0 .

\section{Test Results for the Goodness of Fit (GoF) Value}

Goodness of Fit (GoF) describes the level of suitability of the overall model calculated from the residual squares on the predicted model compared to the actual data.

- Small Goodness of Fit $(\mathrm{GoF})=0.10$

- Medium Goodness of Fit $(\mathrm{GoF})=0.25$

- Large Goodness of Fit $(\mathrm{GoF})=0.38$

$G o F=\sqrt{\overline{A V E} \times R^{2}}=0,588$ 
From the calculation of Goodness of Fit (GoF) above, it can be seen that the result is 0.588 which can be categorized as Large Goodness of Fit (GoF) because it is more than 0.38. This indicates that the performance between the measurement model (outer model) and the structural model (inner model) has a large Goodness of Fit that is equal to 0.588 , which means the model in this study is appropriate and feasible to use.

\section{Multiple Linear Regression Analysis Test Results.}

Table 1 Test Results of Dependent Multiple Linear Regression Analysis of Performance Variables.

\begin{tabular}{cccc}
\hline Model & $\begin{array}{c}\text { Original Sample } \\
(\mathrm{O})\end{array}$ & $\begin{array}{c}\text { Sample Mean } \\
(\mathrm{M})\end{array}$ & $\begin{array}{c}\text { Standard } \\
\text { Deviation }\end{array}$ \\
\hline Selection_Process & 0,357 & 0,350 & 0,138 \\
Training & 0,290 & 0,295 & 0,143 \\
Competence & 0,246 & 0,254 & 0,106 \\
\hline
\end{tabular}

Source: Output of SmartPLS 3.0

Based on the results of the test above, the following multiple linear regression equations are obtained:

$$
\mathrm{KN}=0,357 \mathrm{SP}+0,290 \mathrm{TR}+0,246 \mathrm{CP}
$$

1. Selection Process Variables of $+0,357$ state that the Selection Process has a positive influence on Performance. This means that the better the employee selection process, it will improve employee performance.

2. Training Variables of +0.290 state that Training has a positive influence on Performance. This means that the better the training of employees, it will improve employee performance.

3. Competency Variables of $+0,246$ state that Competence has a positive influence on Performance. This means that the better the competence of employees, it will improve employee performance.

Table 2 Test Results of Dependent Multiple Linear Regression Analysis of Competency Variables

\begin{tabular}{cccc}
\hline Model & Original Sample & Sample Mean & Standard \\
& $(\mathrm{O})$ & $(\mathrm{M})$ & Deviation \\
\hline Selection_Process & 0,272 & 0,292 & 0,136 \\
Training & 0,526 & 0,519 & 0,139 \\
\hline
\end{tabular}

Source: Output of SmartPLS 3.0

Based on the results of the test above, the following multiple linear regression equations are obtained:

$$
\text { KN = 0,272 SP + 0,526 TR }
$$

1. Selection Process Variables of $+0,272$ state that the Selection Process has a positive influence on Competence. This means that the better the employee selection process, it will improve employee competency.

2. Training Variables of $+0,526$ state that Training has a positive influence on Competence. This means that the better the training of employees, it will improve employee competency

\section{Hypothesis Test Results}

Table 3 The results of hypothesis testing in this study can be seen from the table below.

\begin{tabular}{lcc}
\hline \multicolumn{1}{c}{ Exogenous Variable } & T Statistik & P Values \\
\hline Selection-Competence Process & 1,995 & 0,047 \\
Training-Competence & 3,794 & 0,000 \\
Competence-Performance & 2,328 & 0,020 \\
Selection-Performance process & 2,589 & 0,010 \\
Training-Performance & 2,028 & 0,043 \\
Selection-Competence-Performance Process & 1,863 & 0,063 \\
Training-Competence-Performance & 1,422 & 0,156 \\
\hline
\end{tabular}

Source: Output of SmartPLS 3.0

Based on the results of the hypothesis test above it can be seen that:

1. Selection Process of Competence

The results of the hypothesis test for the first hypothesis obtained $\mathrm{T}$ values of statistics of $1.995>1.96$, and $\mathrm{P}$ values of $0.047<0.05$, which means that the selection process has an effect significant to Competence. Hypothesis 1 which states "the selection process has a significant effect on the competence of PT NOK Indonesia employees" means that it is accepted.

2. Training on Competence

The results of hypothesis testing for the second hypothesis obtained a statistical T value of $3.794>1.96$, and $\mathrm{P}$ Values of $0.000<0.05$, which means that training has a positive effect significant to Competence. Hypothesis 2 which states "training has a significant effect on the competencies of PT NOK Indonesia employees" means that it is accepted.

3. Competence on Performance

Hypothesis test results for the third hypothesis obtained T Statistics value of $2.328>1.96$, and P Values of $0.020<0.05$, meaning Competence has a significant effect on Performance. Hypothesis 3 which states 
"competence has a significant effect on the performance of PT NOK Indonesia employees" means accepted.

4. Selection Process for Performance

Hypothesis test results for the fourth hypothesis obtained T statistic values of $2.589>1.96$, and $\mathrm{P}$ values of $0.010<0.05$, which means that the selection process is influential significant to Performance. Hypothesis 4 which states "the selection process has a significant effect on the performance of PT NOK Indonesia employees" means that it is accepted.

5. Training on Performance

The results of hypothesis testing for the fifth hypothesis obtained T-Statistic value of 2.028 $>1.96$, and P Values of $0.043<0.05$, which means that training has a significant effect on performance. Hypothesis 5 which states "training has a significant effect on the performance of PT NOK Indonesia employees" means that it is accepted.

6. Selection Process of Performance with competence as an intervening variable

Hypothesis test results for the sixth hypothesis obtained $\mathrm{T}$ statistics value of $1.863<1.96$, and $\mathrm{P}$ value of $0.063>0.05$, which means that influential training is not significant to performance. Hypothesis 6 which states "the selection process has no significant effect on the performance of PT NOK Indonesia employees with competence as an intervening variable" means to be rejected.

7. Training on Performance with competence as an intervening variable

The results of hypothesis testing for the seventh hypothesis obtained a statistical T value of $1.422<1.96$, and $P$ Values of $0.156>0.05$, which means that influential training is not significant to performance. Hypothesis 7 which states that "training has no significant effect on the performance of PT NOK Indonesia employees with competence as an intervening variable" means being rejected.

\section{CONCLUSIONS AND RECOMMENDATIONS}

Beliefs, skills, experience, personality characteristics, motivation, emotional issues, intellectual abilities and organizational culture have a real effect in improving employee competency and performance. Problems that are often experienced by employees include excessive workload, the level of focusing on low work, the urgency of time, working longer to fulfill orders, the less favorable physical environment, work stress, decreasing work morale and decreasing performance, jobs that are monotonous, repetitive and not varied will encourage a decrease in employee performance. Quality in the process of selecting or seeking employees must be improved and maintained, in order to be able to obtain competent human resources, it can be developed and directed to achieve the goals set by the company. Through various employee training and development activities, HR competencies will be more optimal and lead to increased company performance.

The selection and training process has been used and well understood so that it has a real impact on employee competency and performance. Employee competency as an intervening variable in explaining the effect of the selection and training process on employee performance is not proven. Strong efforts are needed from management to improve employee work competencies through improvements to life, physical, social and family needs.

\section{Bibliography}

Abdillah, W., \& Jogiyanto. 2015. Partial Least Square (PLS) - Altenatif Structural Equation Modeling (SEM) dalam Penelitian Bisnis. Yogyakarta: Andi

Al-Mzary, M. M.M., Al-rifai, A. D. A., \& Al-Momany, M. O. E. 2015. Trainning and its Impact on the Perfomance of Employees at Jordanian Universities from the Perspektive of Employee: The Case of Yarmouk University. Journal of Education and Practice. Vol. 6(32)

Alsabbah, M. Y. A., \& Ibrahim, H. 2014. HRM Practices and Employee Competence: A General System Perspective. International Journal of Business, Economics and Law. Vol. 4

Asfaw, A. M., Argaw, M, D., \& Bayissa, L. 2015. The Impact of Training and Development on Employee Perfomance and Effectiveness: A Case Study of District Five Administration Office, Bole Sub-City Ababa, Ethiopia. Journal of Human Resource and Sustainability Studies. Vol. 3: 188-202. Published Online December 2015 in SciRes. http://www.scrip.org/journal/jhrss http://dx.doi.org/10.4236/jhrss.2015.34025

Ataunur, I., \& Ariyanto, E. 2015. Pengaruh Kompetensi dan Pelatihan Terhadap Kinerja Karyawan PT. Adaro Energy Tbk. Telaah Bisnis. Vol. 16(2)

Dwihatmojo, S., Nelwan, O. S., \& Kawet, R. C. 2016. Rekrutmen, Pelatihan dan Pembagian Kerja Pengaruhnya Terhadap Kinerja Karyawan pada CV. Jati Jaya Meubel Amurang. Jurnal Riset Ekonomi, Manajemen, Bisnis dan Akuntansi. 4(1): 011-130

Ekaningsih, A. S. 2013. Peran Pendidikan dan Pelatihan serta Kompetensi dalam Upaya Peningkatan Kualitas Sumber Daya Aparatur (Studi pada Dinas Perhubungan Kota Tarakan). Jurnal Borneo. Vol. 9(2)

Ekwoaba, J. O., Ikeije, U. U., \& Ufoma, N. 2015. The Impact of Recruitement and Selection Criteria on Organization Perfomance. Global Journal of Human Resource Management. 3(2): 22-23. Published by European Centre for Research Trainning and Development UK (www.eajournals.org)

Edison, E., Anwar, Y., \& Komariyah, I. 2017. Manajemen Sumber Daya Manusia. Bandung: Alfabeta 
F, Ahrul Tsani. 2013. Pengaruh Kompetensi, Penempatan Kerja dan Motivasi Terhadap Kinerja Pegawai Sekretariat Jenderal Kementerian Luar Negeri. Jurnal Mix. III(1): 12-23

Faradina, D. 2013. Pengaruh Rekrutmen Dan Pelatihan Terhadap Kompetensi Karyawan (Studi pada PT Perkebunan Nusantara III Cabang Kantor Direksi Medan) [Skripsi]. Medan (ID): Universitas Sumatera Utara

Ghozali, I. 2016. Aplikasi Analisis Multivariate dengan Program IBM SPSS 23. Semarang: Badan Penerbit Universitas Diponegoro

Ghozali, I., \& Latan, H. 2015. Partial Least Square Konsep, Teknik dan Aplikasi Menggunakan Program SmartPLS 3.0. Semarang: Badan Penerbit Universitas Diponegoro

Kartodikromo, E. A., Tewal, B., \& Trang, I. 2017. Proses Rekrutmen, Seleksi, Pelatihan Kerja dan Pengaruhnya pada Kinerja Karyawan CV. Celebes Indonesia Sakti Mer 99 Mega Mas Manado. Jurnal EMBA. 5(2): 354272

Khan, R. A. G., Khan, F. A., \& Khan, M. A. 2011. Impact of Trainning and Development on Organizational Perfomance. Global Journal of Management and Business Research. Vol. 11(7)

Kurniawan, R., Hasibuan, S., \& Nugroho, R. E. 2017. Analisis Kriteria dan Proses Seleksi Kontraktor Chemical Sektor Hulu Migas: Aplikasi Metode Delphi-AHP. Mix: Jurnal Ilmiah Manajemen. Vol. VII(2): 252-266

Mangkunegara, A. A. A. P. 2015. Manajemen Sumber Daya Manusia Perusahaan. Bandung: PT Remaja Rosdakarya

Marwansyah. 2016. Manajemen Sumber Daya Manusia. Bandung: Alfabeta

Nassazi, A. 2013. Effect of Trainning on Employee Perfomance [Thesis]. Uganda (ID): Vaasan Ammattikorkeakoulu University of Applied Science

Nurzaman, N. 2016. Pengaruh Pelatihan, Kompetensi dan Motivasi Terhadap Kepuasan Kerja Serta Implikasinya pada Kinerja Pegawai Universitas Islam Negeri Sunan Gunung Djati Bandung [Thesis]. Bandung (ID): Universitas Pasundan Bandung

Oaya, Z. C. T., Ogbu, J. O., \& Remilekun, O. G. 2017. Impact Recruitment and Selection Strategy on Employees Performance: A Study of Three Selected Manufacturing Companies in Nigeria. International Journal of Innovation and Economic Development. 3(2): 32-34

Onyango, J. W., \& Wanyoike, D. M. 2014. Effect of Trainning on Employee Perfomance: A Survey of Health Workers in Siaya Country, Kenya. European Journal of Material Sciences. Vol. 1(1): 11-15

Potale, B. R., Viktor, L., \& Silcyljeova, M. 2016. Pengaruh Proses Rekrutmen dan Seleksi Terhadap Kinerja Karyawan pada PT Bank Sulutgo. Jurnal Berkala Ilmiah Efisiensi. Vol. 16(4)

Purnomo, D., Sudana, I. P., \& Mananda, I GPB. S. 2016. Pengaruh Pendidikan dan Pelatihan Terhadap Kompetensi serta Dampaknya pada Kinerja Pramuwisata Bali. Jurnal IPTA. Vol. 4(2)

Raharjo, S., Paramita, D. P., \& Warso, M. M. 2016. Pengaruh Kemampuan Kerja, Pengalaman dan Pelatihan Terhadap Produktivitas Kerja Karyawan dengan Kompetensi Kerja sebagai Variabel Intervening (studi kasus pada KUD "PATI KOTA" kabupaten bali). Journal Of Management. Vol. 2(2)

Rantesalu, A., Mus, A. R., Mapparenta \& Arifin, Z. 2016. The Effect of Competence, Motivation and Organizational Culture on Employee Perfomance: the Mediating Role of Organizational Commitment. Journal of Research in Business and Management. Vol. 4(9): 08-14.

Rizki, M. 2017. Pengaruh Rekrutmen, Seleksi, dan Kompetensi Terhadap Kinerja Karyawan KFC Di Klaten [Skripsi]. Surakarta (ID): Universitas Muhammadiyah Surakarta

Saluy A B, Musanti T, Mulyana B.2019. Pengaruh Pelatihan, Motivasi Kerja Dan Kompetensi Terhadap Kinerja Personel Di Makosek Hanudnas I, Journal Of Management And Business Review, jilid 16, terbitan 1, halaman 87-109.

Setiawan, V., \& Hidayat, R. 2015. Pengaruh Metode Pelatihan Terhadap Kompetensi Karyawan NDT (Non Destructive Test) Pada PT XZY. Jurnal Akuntansi, Ekonomi dan Manajemen Bisnis. 3(2): 142-149

Simamora, H. 2015. Manajemen Sumber Daya Manusia. Yogyakarta: Aditya Media

Sitorus, T., \& Ghozi, A. 2014. Efek Mediasi Kompetensi Atas Pengaruh Proses Seleksi Pegawai Terhadap Persepsi Kinerja Pegawai (Studi Empirik Pada Pegawai Inspektorat Jendral Kementerian Agama tahun 2014). Jurnal Magister Manajemen. Vol. 9(1)

Sugiyono. 2017. Metode Penelitian Kuantitatif, Kualitatif, dan R\&D. Bandung: Alfabeta

Suparyadi. 2015. Manajemen Sumber Daya Manusia. Yogyakarta: Andi

Sutrisno, E. 2016. Manajemen Sumber Daya Manusia. Jakarta: Kencana

Suwatno \& Priansa, D. J. 2016. Manajemen SDM. Bandung: Alfabeta

Utami, D.H. 2013. Pengaruh Proses Rekrutmen dan Seleksi Terhadap Kompetensi Pengurus DPD Partai XYZ Kota Bogor [Skripsi]. Bogor (ID): Institut Pertanian Bogor

Warsinah. 2014. Proses Seleksi dan Pelatihan Terhadap Kompetensi dan Dampaknya Terhadap Kinerja Karyawan Pada PT Jaya Konstruksi MP Tbk. [Skripsi]. Jakarta (ID): Universitas Mercu Buana

Wisastra, P. I. Y., \& Sagala, E. J. 2016. Pengaruh Pelatihan Terhadap Kompetensi Karyawan PT LEN Industri (Persero) Bandung. Jurnal Manajemen, Strategi Bisnis dan Kewirausahaan. Vol. 10(2) 